\title{
SUPPLIER INVOLVEMENT IN NEW PRODUCT DEVELOPMENT: A STUDY IN THE BRAZILIAN FOOTWEAR INDUSTRY
}

\section{Diego Castro FETTERMANN ${ }^{1 *}$, Márcia Elisa Soares ECHEVESTE ${ }^{2}$, André SAIDEL ${ }^{2}$, Guilherme Luz TORTORELLA ${ }^{1}$}

${ }^{1}$ Federal University of Santa Catarina, Department of Industrial Engineering and Systems, Florianopolis, Brazil, d.fettermann@ufsc.br, gluztortorella@gmail.com

${ }^{2}$ Federal University of Rio Grande do Sul, Department of Industrial Engineering and Statistics, Porto Alegre, Brazil, echeveste@producao.ufrgs.br, aseidel@masterskills.com.br

\section{SUPPLIER INVOLVEMENT IN NEW PRODUCT DEVELOPMENT: A STUDY IN THE BRAZILIAN FOOTWEAR INDUSTRY}

\begin{abstract}
The supplier involvement in the New Product Development (NPD) has become an important contribution to the solution of problems, which causes the process to be faster and more productive. However, it is still difficult to manage the supplier involvement during the NPD process. This study evaluates benefits and success factors of the supplier involvement during the process of NPD among three companies from the footwear industry in Sinos Valley/Brazil. The method developed indicates which items must be implemented as common objectives between company and supplier, as well as the most influential points for the success of the partnership. The results present an array of opportunities for the improvement of the partnership between company and suppliers.
\end{abstract}

KEY WORDS: success factors, Sinos Valley, supply chain management

\section{IMPLICAREA FURNIZORILOR ÎN DEZVOLTAREA DE NOI PRODUSE: UN STUDIU AL INDUSTRIEI BRAZILIENE DE ÎNCĂLJĂMINTE}

REZUMAT. Implicarea furnizorilor în dezvoltarea noilor produse a devenit o contribuţie importantă la soluţionarea problemelor, ceea ce face ca procesul să fie mai rapid şi mai productiv. Cu toate acestea, încă există dificultăţi în gestionarea implicării furnizorilor în procesul de dezvoltare a noilor produse. Acest studiu evaluează beneficiile şi factorii de succes ai implicării furnizorilor în procesul de dezvoltare a noilor produse în trei companii din industria de încălțăminte din Valea Sinos/Brazilia. Metoda dezvoltată indică elementele care trebuie să fie puse în aplicare ca obiective comune ale companiei şi furnizorilor, precum şi punctele cele mai influente pentru succesul parteneriatului. Rezultatele prezintă o serie de oportunităţi pentru îmbunătăţirea parteneriatului dintre companie şi furnizori.

CUVINTE CHEIE: factori de succes, Valea Sinos, gestiunea lanţului de aprovizionare

\section{PARTICIPATION DES FOURNISSEURS AU DÉVELOPPEMENT DE NOUVEAUX PRODUITS: UNE ÉTUDE DANS L'INDUSTRIE BRÉSILIENNE DES}

\section{CHAUSSURES}

RÉSUMÉ. L'implication du fournisseur dans le développement de nouveaux produits (NPD) est devenue une contribution importante à la solution des problèmes, ce qui rend le processus plus rapide et plus productif. Cependant, il est encore difficile de gérer la participation du fournisseur au cours du processus de NPD. Cette étude évalue les avantages et les facteurs de succès de la participation des fournisseurs au cours du processus de NPD auprès de trois entreprises de l'industrie de la chaussure de la vallée de Sinos / Brésil. La méthode développée indique quels éléments doivent être mis en œuvre comme objectifs communs entre entreprise et fournisseur, ainsi que les points les plus influents pour le succès du partenariat. Les résultats présentent un éventail d'opportunités pour l'amélioration du partenariat entre la société et les fournisseurs.

MOTS CLÉS: facteurs de succès, vallée de Sinos, gestion de la chaîne logistique

\section{INTRODUCTION}

The efficient integration of competences and resources between companies has become a requirement in order to compete in a globalized economy [1]. At first, such integration activities were centered in the agility of product delivery, in the quality guarantee during production, in logistics and in cost reduction. However, given the fact that these issues tend to be standardized, the focus shifted on to New Product Development (NPD), mainly to the relations that the company establishes with its suppliers [2-4]. Therefore, the reduction in product lifecycles and the competitive pressures caused by technology update also lead the company to integrate both clients and suppliers, especially as a way to add value to its supply chain [5].

There is still a growing participation of suppliers in the company results, mainly because the purchase of raw materials determines an estimate of $50 \%$ of its cost $[6,7]$. Moreover, more than $70 \%$ of the final cost in the world automotive industry is generated by the suppliers [8]. In addition to the pressures for cost reduction made by the manufacturers on their suppliers, which varies from 5 to $8 \%$ a year, the continuous improvement of product quality and the reduction in time development demand

* Correspondence to: Diego Castro FETTERMANN, Federal University of Santa Catarina (UFSC), Campus Trindade, Technology Center - CTCEPS. Postal Box 476, CP88040-900, Florianópolis-Brazil. d.fettermann@ufsc.br 
from the supplier some constant update and a growing influence in the result of the client company [9].

The supplier involvement in the NPD has become an important contribution to the solution of problems, which causes the process to be faster and more productive $[6,7]$. However, it has not yet been made clear how and when it is appropriate to cooperate with the suppliers during the development process [10-12], this issue being one of the most important areas to be developed within the scope of NPD [13]. Recent studies have brought little understanding on how the suppliers should contribute to the process as well as the aspects to ensure the positive results for such relationship $[14,15]$.

Therefore, this study evaluates benefits and success factors of the relationship between company and supplier during the process of NPD. This contribution starts with the identification and measurement of the importance of all benefits as well as the success factors that influence the performance of a cooperative relationship with the supplier during NPD. In order to carry out this study, three companies from the footwear sector in Brazil have been selected along with their most strategic suppliers for the establishment of such partnership.

Brazil is the third largest footwear manufacturer in the world after China and India and the sixth among the largest exporters [16]. The Brazilian footwear cluster of the Sinos Valley was chosen because it is a showcase for successful integrations into global chains from a developing country $[17,18]$. Therefore, this case is based also on the depth of the cooperation between companies and their suppliers $[16,19]$.

\section{BENEFITS AND THE SUCCESS FACTORS OF THE COOPERATIVE RELATIONSHIP WITH THE SUPPLIER DURING NPD}

The benefits and the success factors that match the performance of the cooperative process have been researched in order to provide a better NPD cooperative performance between companies and their suppliers. Such benefits and factors have been classified according to the subsystems that make up the social-technical system [20]. These authors regarded sociotechnical systems as subdivided into four interrelated subsystems: personnel, technological, work design and external environment. In this study, the social-technical system approach is used to classify the issues related to the work system between the company and its suppliers, more specifically to the cooperative relationship during NPD.

\section{Technological Subsystem}

Among the subsystems that make up the social-technical system, the technological one aims to identify the way in which technology influences the organizations' work system [20]. In this study, the issues related to the technological development as well as the tools used during the cooperative relationship with the supplier in NPD are classified (Table 1).

\section{Personal Subsystem}

This subsystem focuses on the influences by which the work system participants' characteristics and qualification determine the result of the project. According to Pasmore [45], this is the subsystem that allows the creation, modification and the improvements within the organization, because human beings are the sources for adaptation, innovation, idealization and inspiration inside the organization. Thus, the issues towards the agents' qualification and knowledge who take part of the cooperation are grouped in the personal subsystem (Table 2).

\section{External Environment Subsystem}

Being an open system, the social-technical one holds a close relationship with the environment in which it is inserted through a constant exchange of information and influences. Therefore, the organization depends on its capacity to adapt to the external context constantly in addition to the monitoring of the environment as to provide the necessary adjustments to these modifications [20]. According to Pasmore [45], the influences the organization receives from the external environment can be classified within the external environment subsystem as follows: governmental, regulatory, ecological, logistic, commercial, financial, among others (Table3).

\section{Work Project Subsystem}

As stated by Hendrik and Kleiner [20], the variables the other three subsystems comprise (technological, personal, and external environment) exert influences upon themselves and upon work structure, considering that the work design subsystem is capable of interacting with the variables in the other subsystems in 
Table 1: Benefits and success factors classified in the technological subsystem

\begin{tabular}{lll}
\hline & Benefits of the cooperation & References \\
\hline B1 & Increase the number of patents & {$[21]$} \\
B2 & Improve product quality & {$[2,5-8,22-37]$} \\
B3 & Develop better manufacturing & {$[31,38]$} \\
B4 & Product cost reduction & {$[6-8,25,28,30-32,34-37,39,40]$} \\
B5 & Process cost reduction & {$[6,8,25,28,30,32,34-36,39,40]$} \\
\hline & Success Factors of the cooperation & References \\
\hline S1 & Supplier's component costs in the product final value & {$[34,41]$} \\
S2 & Product greater complexity & {$[5,33,42]$} \\
S3 & Use of FMEA and QFD with the supplier & {$[32,42]$} \\
S4 & Use of DFM and DFA with the supplier & {$[32,42]$} \\
S5 & Use of a supplier's ranking system & {$[6,23,24,31,32,44]$} \\
S6 & CAD/CAE compatible systems & {$[6,31,34,44]$} \\
\hline
\end{tabular}

Table 2: Benefits and success factors classified in the personal subsystem

\begin{tabular}{lll}
\hline & Benefits of the cooperation & References \\
\hline B6 & Learning opportunities in the cooperation & {$[46]$} \\
B7 & Increase the supplier's motivation & {$[32]$} \\
B8 & Access to competences and knowledge & {$[7,8,24,29,31,32,36,42,46-55]$} \\
B9 & Innovation source & {$[7,11,29,34,36,46,48,52,54]$} \\
B10 & Development time reduction & {$[7,22,23,25,27-30,32-36,39,52,54]$} \\
\hline & Success factors of the cooperation & References \\
\hline S7 & Suppliers' knowledge/technology & {$[7,23,40,43,56]$} \\
S8 & Cultural similarity & {$[22,23,29,43,57]$} \\
S9 & Information/control of the supplier's operations & {$[35,52]$} \\
S10 & Use of Guest engineers & {$[3,23,35]$} \\
S11 & Low Asymmetric Information between Companies & {$[50,51]$} \\
\hline
\end{tabular}

Table 3: Benefits and success factors classified in the external environment subsystem

\begin{tabular}{lll}
\hline & Benefits of the cooperation & References \\
\hline B11 & Joint investments in R\&D & {$[24,36]$} \\
B12 & Comply with environmental and governmental rules & {$[7]$} \\
B13 & Reduction of risk/uncertainty in NPD & {$[7,24,31,36,47,48,52,58]$} \\
\hline & Success factors of the cooperation & References \\
\hline S12 & Low differences between company sizes & {$[34]$} \\
S13 & Low uncertainty of environment & {$[7,24,31,50,56]$} \\
S14 & Type of relationship governance & {$[11,24,46,59]$} \\
S15 & High integration of the production chain & {$[34,59]$} \\
S16 & Confidence in the supplier's performance & {$[7,31]$} \\
S17 & Low risk of loss of copyright & {$[52]$} \\
S18 & Low pressure for cost reduction & {$[24,25,27,35,60]$} \\
\hline
\end{tabular}

order for the company to achieve better results. In this study, the issues related to the procedures used in the cooperation with the supplier during NPD are grouped in the work design subsystem (Table 4).

The benefits and the success factors mentioned in the references were used to develop a close-end questionnaire in order to identify the importance of company's perception and its strategic suppliers in relation to each benefit and success factor. The classification of these questions in the subsystems of the socialtechnical system allows the comprehensive identification of the subsystems that exert greater 
Table 4: Benefits and success factors classified in the work project subsystem

\begin{tabular}{lll}
\hline & Benefits of the cooperation & References \\
\hline B14 & Workload decrease in DP & {$[8,23,30,61]$} \\
B15 & Flexibility in NPD & {$[7,22,23]$} \\
\hline & Success factors of the cooperation & References \\
\hline S19 & Physical proximity & {$[27,34]$} \\
S20 & Relationship with a few suppliers & {$[3,7,24,25,29,43,46,50,60]$} \\
S21 & Long-term relationship with the supplier & {$[7,24,25,27,29,46,51,53,60,61]$} \\
S22 & High flow of information exchange & {$[5,24,28,31,34,35,52,56,61]$} \\
S23 & Communication with direct contacts & {$[27,52]$} \\
S24 & Informal meeting for the Exchange of information & {$[24,64]$} \\
S25 & Managing the cooperation between client and supplier & {$[6,26,36]$} \\
S26 & Integration of the project team & {$[6,23,24,26,28,34,36,39,42,49,56,61,63,64]$} \\
S27 & Articulate common goals and objectives & {$[7,31,52,65]$} \\
S28 & Moment when the supplier must cooperate in NPD & {$[7,13,22,43,66]$} \\
S29 & Company's internal integration & {$[65]$} \\
S30 & No use of poor communication & {$[27,28,52]$} \\
S31 & Frequent communication & {$[22,38]$} \\
S32 & Use of Concurrent engineering & {$[28,32]$} \\
S33 & Increase of NPD complexity with supplier participation & {$[28,51]$} \\
S34 & Possibility of cooperation inefficiency & {$[58,21]$} \\
S35 & Information dispersion & {$[28,50]$} \\
\hline
\end{tabular}

impact upon the cooperative NPD performance between company and suppliers.

\section{RESEARCH METHOD}

The multiple-case study method with a theoretical replication [67] was due to the diversity of shoe companies in Sinos Valley, Brazil and to the lack of similar studies about this sector. Three companies were selected, developed in the company is also replicated in the identified suppliers, which completes the company study. The case study format both in the company and in its respective suppliers is illustrated in Figure 1.

A close-end questionnaire has been applied in order to measure the importance of benefits and success factors for the cooperative relationship between client and supplier during

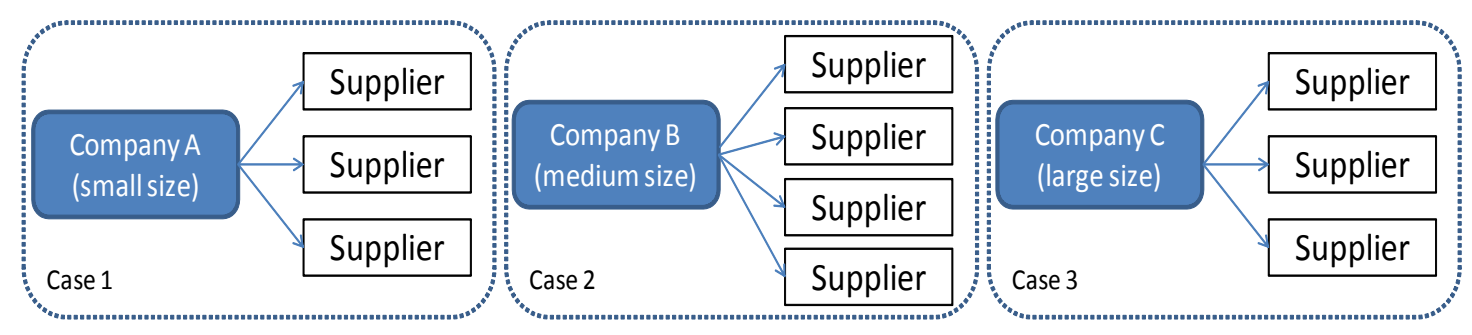

Figure 1. Research amplitude demonstration

and their size was used as the criterion for the differentiation between them. For the company case study, interviews with product and supply chain manager were used which also identify the suppliers that already develop any sort of cooperative relationship with the company during its NPD. Subsequently, part of the analysis
NPD, pointing out each benefit and success factor identified in the referenced literature (Tables 1-4). Respondents are then invited to express their opinions on each benefit and success factor through a $15 \mathrm{~cm}$ continuous assessment scale, as proposed by Stone et al. [68]. The intensity of each response may vary between 0 and 15 
according to the question: (i) low importance (0)/ high importance (15) of the benefits or success for the cooperative relationship.

The analysis of the data collected from questionnaire follows three phases: questionnaire reliability, intra-group analysis and performance of subsystems. In the first phase, the analysis of the questionnaire reliability was carried out through Cronbach's alpha [69, 70], which aims to evaluate the questionnaire internal reliability.

As a means of identifying the tendency towards the difference or the similarity between the company's and its suppliers' answers, the intra-group analysis, it has been developed a descriptive statistics method made up of three phases: i) calculate the mean between each company's suppliers, ii) for each question compare the difference in module between the suppliers' mean and the company's answers; iii) calculate the quartiles for the difference result of the company's answers in module and the suppliers' questions mean. The result is the identification of $25 \%$ of the greatest and the smallest differences between the company's answers to each question and the suppliers' mean, that is, the questions where it is possible to identify a greater agreement and disagreement tendency between the company's opinion and its suppliers'. inserted in each subsystem, the Analysis of Variance (ANOVA) has been used. In case the tendency towards the influence difference of subsystems in the benefits or success factors is found, the multiple comparison test (LSD) is applied in order to identify which subsystems tend to exert greater influence upon the benefits and the success factors.

\section{RESULTS}

Both Company A (small size) and Company C (big size) exclusively produce women's shoes, whereas Company B (medium size) mainly produces children's shoes but also women's and sports shoes in smaller quantities. All companies only trade their products using their own brands, and Companies A (small) and C (big) own only one brand. Company B (medium) owns seven different brands, and it happens because this company is a branch of a bigger and older textile group, which has the legal rights. The characterization of these three companies is illustrated in Table 5.

Company A (small size) identified three suppliers as potential partners in order to establish a cooperative relationship during NPD, and these suppliers have maintained a relationship with the company since the start of the activities. Moreover, they are located near the company and have similar number of

Table 5: Characterization of the three companies

\begin{tabular}{lccc}
\hline & Company A & Company B & Company C \\
& (small size) & (medium size) & (big size) \\
\hline Daily production & 1300 pairs/day & 9500 pairs/day & 45000 pairs/day \\
Number of employees & 40 employees & 984 employees & 2500 employees \\
Start of activities & 1998 & 2000 & 1955 \\
Main product & Feminine & Children (mainly) & Feminine \\
Materials most used in & Leather, Polyurethane (PU) & Polyvinyl chloride (PVC) and & cloth \\
the upper & and Polyvinyl chloride (PVC) & Polyurethane (PU) \\
Materials most used in & Polyurethane (PU) and & Polyurethane (PU) & Polyurethane (PU) \\
the outsole & Polyvinyl chloride (PVC) & & \\
\hline
\end{tabular}

The third phase, the performance of subsystems (technological, personal, external environment and work design) seeks to identify the subsystems exerting the greater influence upon the performance of the cooperative relationship between company and supplier during NPD. In order to identify the significant differences in the importance of the questions employees. Company B selected four suppliers to take part in the research, which have also maintained a relationship with the company since the start of the activities. The selected suppliers are located in Sinos Valley and have fewer employees than the company. Company C (big size) selected three suppliers, which are located in Sinos Valley and have a varied number 
of employees, being greater that the company in one case. The description of the raw materials the selected suppliers deliver as well as the start of the activities with the company are represented in Table 6.
The amplitude of the inter- interquartile difference between the company's answers and its suppliers' indicates, in a broader way, a tendency towards a greater agreement or disagreement in relation to the importance

Table 6: Suppliers the companies selected to take part in the study

\begin{tabular}{|c|c|c|c|c|c|c|}
\hline \multirow{6}{*}{$\begin{array}{l}\frac{n}{0} \\
\frac{\underline{0}}{0} \\
\frac{0}{2} \\
\sim\end{array}$} & \multicolumn{2}{|c|}{ Company A (small size) } & \multicolumn{2}{|c|}{ Company B (medium size) } & \multicolumn{2}{|c|}{ Company C (big size) } \\
\hline & Raw material & Start & Raw material & Start & Raw material & Start \\
\hline & Packaging & 1999 & Components & 2000 & Chemicals & 1992 \\
\hline & PU Outsoles & 1999 & Fabrics & 2000 & Outsoles & 1992 \\
\hline & Components & 1999 & Liners & 2000 & Liners & 1994 \\
\hline & & & Components & 2000 & & \\
\hline
\end{tabular}

\section{Questionnaire Reliability}

The answers of the questionnaire have been submitted to a reliability test, which have been well interpreted both by the three companies and by their respective suppliers. This can be verified through a Cronbach alpha greater than 0.6, which according to Hair Jr. et al. [70] represents the acceptable coefficient for exploratory research (Table 7). of the benefits and the success factors of the cooperative relationship. In this sense, Company $B$ (medium size) is the one with a greater tendency towards the agreement in relation to the importance of the benefits of the supplier involvement during NPD (Figure 2), precisely the company from which it was possible to raise more evidence of a cooperative relationship with its suppliers. However, regarding the success

Table 7: Cronbach alpha coefficients for the questionnaire

\begin{tabular}{ccc}
\hline$N$ & Benefits of the supplier involvement & Success factors of the supplier involvement \\
\hline 13 & 0.932 & 0.699 \\
\hline
\end{tabular}

\section{Intra-Group Analysis}

The result of the descriptive statistics method proposed for the interpretation of the data collected from the companies' and their suppliers' answers related to the importance of the questions raised in the literature is illustrated in Table 8. factors, this measure indicates that Company $B$ (medium size) is the one tending to greater disagreement with its suppliers, which points to a greater diversity in the way to achieve the success in the supplier involvement, as it can be observed in the dispersion graph illustrated in Figure 3.

Table 8: Difference between the company's answers and its suppliers' separated in quartiles

\begin{tabular}{llllll}
\hline & Valid Questions & Q1 (25\%) & Q2 (50\%) & Q3 (75\%) & Q3-Q1 \\
\hline Benefits of the supplier involvement & & & & \\
\hline Company A and suppliers & 15 & 1.4807 & 3.3843 & 5.4240 & 3.9433 \\
Company B and suppliers & 15 & 1.2693 & 1.9436 & 2.3000 & 1.0307 \\
Company C and suppliers & 15 & 2.3243 & 2.9707 & 4.6875 & 2.3632 \\
\hline Success factors of the supplier involvement & & & & & 2.4606 \\
\hline Company A and suppliers & 36 & 0.9133 & 1.7865 & 3.3739 & 5.1271 \\
Company B and suppliers & 36 & 0.8066 & 2.7264 & 5.9337 & 5.6875 \\
Company C and suppliers & 36 & 0.9228 & 1.7923 & & 3.7647 \\
\hline
\end{tabular}


BENEFITS -Medium size company n Company $\diamond$ Suppliers

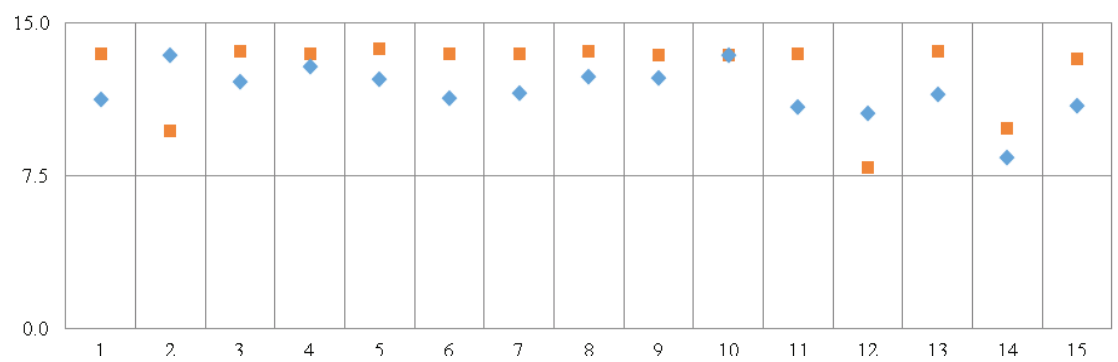

Figure 2. Difference between Company B's answer and the supplier's answer mean related to the benefits

SUCCESS FACTORS - Medium size company

- Company $m$ Suppliers

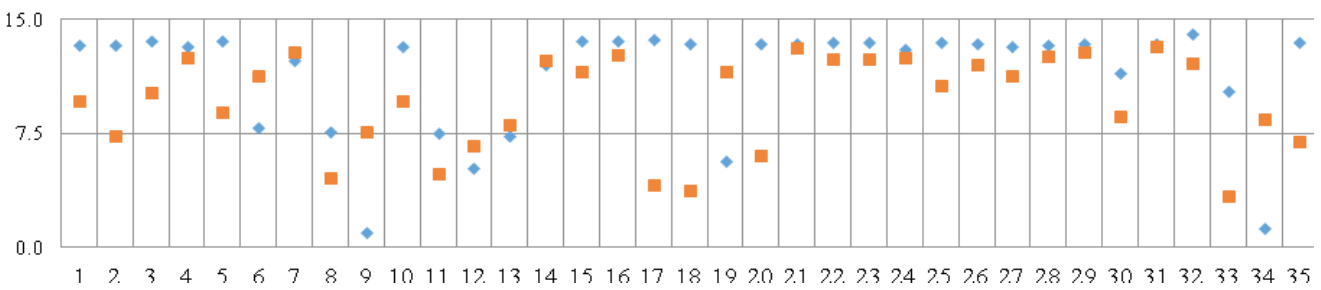

Figure 3. Difference between Company B's answer and the supplier's answer mean related to the success factors

To the benefits of the supplier involvement, the questions where it can be seen the tendency towards disagreement between company and supplier contribute as to diagnose the company's and its supplier's frame of mind. In questions where a greater tendency to agreement (Q1) can be found as well as a greater qualification than the average score, it is recommended that these should be used as potential benefits for the company and its suppliers in the establishment of the cooperative relationship during NPD. The tendencies towards the agreement and the disagreement between company and its suppliers in the questions regarding the benefits of the cooperation are presented in Table 9.

In Company A (small size), the suppliers develop, almost independently, all the components for the company products, and its work consists of adapting the products to fashion tendencies. This company's behavior contributes to the understanding of the tendency towards disagreement regarding the workload decrease in NPD (B14) and the possibility of joint investments in R\&D (B11). Among the questions that tend to agreement, patent development (B1) and reduction of risk in NPD (B13) are points that should be approached as possibilities of gain in the cooperative relationship. However, the possibility of flexibility in NPD (B15), despite the tendency towards agreement between company and suppliers, its qualification did not reach the minimum score of 7.5 in order to be included as an agreement objective for the relationship.

Company B (medium size) is, among the studied companies, the one that is more open to innovation and to the development of technologies for its products. However, a tendency has been found towards disagreement between its suppliers regarding the joint investments in R\&D (B11), in spite of representing an opportunity for development of new materials and techniques [24, 36]. Process cost reduction (B4), development time (B10) and innovation source (B9) are among the questions where there is the tendency towards agreement between company and supplier and can be considered as common objectives.

Company C (big size), as well as the small size company, is also more directed to following fashion tendencies. Nevertheless, it has a much more developed structure, which is able to carry out tests and to develop some components and raw materials. This greater independence contributes to the understanding of the tendency towards disagreement with its suppliers regarding questions about process 
Table 9: Difference between the company's opinion and its suppliers' regarding the benefits of the supplier involvement during NPD

\begin{tabular}{lccc}
\hline \multirow{2}{*}{ Benefits of the supplier involvement } & \multicolumn{3}{c}{ Companies and their suppliers } \\
& Company A & Company B & Company C \\
\hline B1-Increase the number of patents & 0.180 & 2.240 & 2.931 \\
B2-Improve product quality & 3.035 & 3.685 & 2.403 \\
B3-Develop better manufacturing & 2.257 & 1.510 & 0.908 \\
B4-Process cost reduction & 6.356 & 0.626 & 5.326 \\
B5- Product cost reduction & 3.820 & 1.452 & 9.199 \\
B6-Learning opportunities in the cooperation & 2.057 & 2.213 & 2.991 \\
B7-Increase the supplier's motivation & 1.481 & 1.944 & 2.794 \\
B8-Access to competences and knowledge & 6.201 & 1.269 & 1.049 \\
B9-Innovation source & 3.384 & 1.100 & 4.687 \\
B10-Development time reduction & 5.280 & 0.041 & 2.125 \\
B11-Joint investments in R\&D & 5.973 & 2.640 & 4.120 \\
B12-Comply with environmental and governmental rules & 4.502 & 2.663 & 4.130 \\
B13-Reduction of risk/uncertainty in NPD & 0.416 & 2.107 & 8.689 \\
B14-Workload decrease in NPD & 5.424 & 1.426 & 4.519 \\
B15-Flexibility in NPD & 0.453 & 2.300 & 2.324 \\
\hline Company and supplier tend to disagree (Q3) & & & \\
\hline Company and
\end{tabular}

cost reduction (B4), product (B5), and the risk in NPD (B13). Among the questions that should be approached as possibilities of gain from the supplier involvement during NPD, are development of new product manufacturing (B3), access to knowledge (B8), development time reduction (B10) and the possibility of more flexibility in NPD (B15).

Regarding the success factors of the supplier involvement, the questions that show greater disagreement between company and supplier can also be used as a way to diagnose the cooperation with its suppliers, whereas the ones indicating greater tendency to agreement, since all have an average score greater than 7.5, can be used as opportunities of improving the supplier involvement cooperation in NPD. Both the tendencies towards agreement and disagreement regarding the success factors are illustrated in Table 10.

In Company A (small size), the tendency towards agreement comprises mainly questions related to communication (S24, S25, S31, S32) and, indirectly, the long-term relationship with supplier (S22), which according to Ward et al. [61], positively contributes to the communication between company and supplier during NPD. Thus Company A (small size) should prioritize the improvements related to the communication with its suppliers in order to better the performance of its relationship with them during NPD. Since the company does not have more sophisticated mechanisms for the exchange of information with its suppliers, and its communication consists mainly of visits of commercial representatives and the requests for the purchase of raw materials, the implementation of projects focused on the establishment of procedures during the contact between companies, the frequency of these contacts, its quality in addition to better retaining the suppliers, represent potential possibilities of improvement in the supplier involvement during NPD.

In Company $B$ (medium size), there is a greater variety between the success factors that tend towards the agreement between company and supplier. Generally speaking, a predominance of questions regarding NPD (S4, S29, S30) has been found. Despite the fact that the company already uses a suppliers' qualification system, such system does not comprise questions related to NPD. The inclusion of these questions could contribute to improvements in the identification of the moment when the suppliers should take part in the process and in the identification of technologies the supplier has in order to add value to the product. In the questions related to communication, there is also the tendency towards agreement between company and its suppliers $(\mathrm{S} 25, \mathrm{~S} 32)$. In this case, granting the suppliers access to the existing information 
Table 10: Difference between company and its suppliers regarding the success factors of the cooperation

Success factors of the supplier involvement
S1-Supplier's component costs in the product final value
S2-Product greater complexity
S3-Use of FMEA and QFD with supplier
S4-Use of DFM and DFA with supplier
S5-Use of suppliers' ranking system
S6-CAD/CAE compatible systems
S7-Suppliers' knowledge/technology
S8-Cultural similarity
S9-Information/control of the supplier's operations
S10-Use of guest engineers
S11-Low asymmetric information between companies
S12-Low differences between company size
S13-Low uncertainty of environment
S14-Type of relationship governance
S15-High integration of the supply chain
S16-Confidence in the supplier's performance
S17-Low risk of loss of copyright
S18-Low pressure for cost reduction
S19-Physical proximity
S20-Relationship with a few suppliers
S21-Long-term relationship with the supplier
S22-High flow of information exchange
S23-Communication with direct contacts
S24-Informal meeting for the exchange of information
S25-Managing the cooperation between client and supplier
S26-Integration of the project team
S27-Articulate common goals and objectives
S28-Moment when the supplier must cooperate in NPD
S29-Company's internal integration
S30-No use of poor communication
S31-Frequent communication
S32-Use of concurrent engineering
S33-Increase of NPD complexity with supplier participation
S34-Possibility of cooperation inefficiency
S35-Information dispersion
Company and supplier tend to disagree (Q3)
Company and supplier tend to agree (Q1)

management system during NPD, besides projects allowing a greater integration with its partners, such as joint training courses to the company's and suppliers' development team. The other questions where tendency towards agreement can be found are directed to relationship risk reduction (S14, S15). In this sense, setting more complete contracts and showing the supplier the planning of cooperation activities and objectives contribute to some better understanding of the relationship and a gradual risk reduction. The long-term relationship with suppliers also represents an alternative to increase the supplier's confidence when it comes to keeping the partnership [24].

In Company C (big size), a tendency has been found towards agreement with the success factors related to NPD (S2, S6, S7, S33, S35). Given the fact that a company's product development is a fairly restricted process even to employees,

\begin{tabular}{|c|c|c|}
\hline \multicolumn{3}{|c|}{ Companies and their suppliers } \\
\hline Company A & Company B & Company C \\
\hline 3.440 & 3.695 & 3.335 \\
\hline 1.911 & 5.970 & 0.903 \\
\hline 1.045 & 3.450 & 1.220 \\
\hline 1.755 & 0.702 & 1.467 \\
\hline 1.150 & 4.734 & 1.770 \\
\hline 9.520 & 3.398 & 0.331 \\
\hline 1.650 & 0.537 & 0.273 \\
\hline 2.210 & 2.998 & 0.929 \\
\hline 6.266 & 6.613 & 1.071 \\
\hline 3.947 & 3.562 & 0.314 \\
\hline 0.549 & 2.620 & 1.326 \\
\hline 3.040 & 1.457 & 1.815 \\
\hline 1.786 & 0.762 & 1.190 \\
\hline 0.546 & 0.336 & 2.721 \\
\hline 1.985 & 2.014 & 0.323 \\
\hline 0.194 & 0.939 & 1.149 \\
\hline 2.185 & 9.618 & 6.707 \\
\hline 2.709 & 9.674 & 9.836 \\
\hline 1.143 & 5.825 & 0.127 \\
\hline 5.359 & 7.363 & 1.731 \\
\hline 0.224 & 0.236 & 0.982 \\
\hline 1.014 & 1.096 & 1.448 \\
\hline 0.154 & 1.103 & 5.104 \\
\hline 0.823 & 0.561 & 8.678 \\
\hline 1.414 & 2.833 & 7.633 \\
\hline 1.394 & 1.361 & 6.377 \\
\hline 3.808 & 1.877 & 3.763 \\
\hline 1.004 & 0.762 & 6.636 \\
\hline 3.308 & 0.566 & 2.697 \\
\hline 0.540 & 2.907 & 2.035 \\
\hline 0.219 & 0.143 & 3.774 \\
\hline 1.432 & 1.916 & 0.730 \\
\hline 1.876 & 6.962 & 2.707 \\
\hline 4.762 & 7.105 & 0.204 \\
\hline 1.531 & 6.572 & 4.303 \\
\hline
\end{tabular}

not to mention to suppliers, opening this process to key suppliers could help foster participation. Setting a system of hierarchy and selection of suppliers, which includes in its assessment the capacity to cooperate during NPD would contribute for the company to consider the supplier's technology, as well as the use of compatible mechanisms, such as CAD/CAE, in addition to minimizing the chances of failure of the relationship. The other success factors where there is a tendency towards agreement are directed to the integration between companies (S11, S16, S20). In this sense, the company's capacity to conduct the majority of activities internally, reduces the suppliers' participation in the process. However, projects that intensify the relations between companies, such as the exchange of technical information, the practice of guest engineers, as well as the intensification of the relationship with local suppliers would 
contribute to a better performance of the supplier involvement during NPD.

\section{Performance of Subsystems}

In order to carry out this analysis, all respondents' answers to the close-end questionnaire have been included $(\mathrm{N}=13)$. The questionnaire is made up of 15 questions related to the benefits and other 35 related to success factors. The ANOVA [71, 72] result shows that there are significant differences between the influence of the subsystems in the relationship both in the benefits $(F=7,767 ; p$ value $<0,000)$ and in the success factors $(F=11,340 ; p$ value $<0,000)$. Regarding the benefits of the supplier involvement, the test of multiple comparisons (LSD) shows that the questions comprised in the personal and technological subsystems tend to be more valued by the companies and their suppliers (Table 11).

In relation to the success factors of the supplier involvement, it was identified a tendency to which the questions comprised in the work design and technological subsystems have greater influence over the result of the cooperative relationship during NPD (Table 12).

In this sense, it is suggested that in the studied cases, the companies focus more on the questions comprised in these subsystems in order to achieve their objectives during the supplier involvement. The technological subsystem is used in this study to include the questions related to technology and the use of tools in the relationship with the supplier during NPD. The work design subsystem comprises questions directed to the procedures adopted during the performance of activities, in other words, to the work structure. This tendency towards the valuation of the questions comprised in the technological subsystem and work design should not be seen as a means of reducing the importance of the other subsystems. However, they can point to the priority of the questions included in these subsystems.

\section{CONCLUSIONS}

The analytical method used was considered effective in order for the companies to identify the possibilities of improving the performance of the supplier involvement during NPD, as well as the setting of common goals during the process. On the one hand, the benefits on which the companies tend to agree are presented as synergy possibilities that should be adopted during the cooperative NPD. On the other hand, the success factors on which the companies

Table 11: Test of multiple comparisons (LSD) for the benefits of the supplier involvement

\begin{tabular}{lcccc}
\hline Subsystem & Average & $\begin{array}{c}\text { Personal } \\
\text { subsystem }\end{array}$ & $\begin{array}{c}\text { Technological } \\
\text { subsystem }\end{array}$ & $\begin{array}{c}\text { External environment } \\
\text { subsystem }\end{array}$ \\
\hline Work design subsystem & 8,70 & $-2.95^{* *}$ & $-2.29^{* *}$ & -1.1246 \\
Personal subsystem & 11,66 & - & 0.66 & $1.8333^{* *}$ \\
Technological subsystem & 11,00 & $-1733^{*}$ \\
External environment subsystem & 9,82 & & & - \\
\hline
\end{tabular}

* significant at $5 \%$ - ** significant at $1 \%$

Table 12: Test of multiple comparisons (LSD) for the success factors of the supplier involvement

\begin{tabular}{lcccc}
\hline Subsystem & Average & $\begin{array}{c}\text { Personal } \\
\text { subsystem }\end{array}$ & $\begin{array}{c}\text { Technological } \\
\text { subsystem }\end{array}$ & $\begin{array}{c}\text { External environment } \\
\text { subsystem }\end{array}$ \\
\hline Work design subsystem & 10.87 & $2.24^{* *}$ & -0.29 & $1.25^{* *}$ \\
Personal subsystem & 8.62 & - & $-2.54^{* *}$ & -0.99 \\
Technological subsystem & 11.16 & - & $1.54^{* *}$ \\
External environment subsystem & 9.61 & & - \\
\hline
\end{tabular}

* significant at $5 \%$ - ** significant at $1 \%$ 
agreed tend to indicate the questions that have stronger impact on the result of the supplier involvement during NPD process.

It was found a higher valuation of questions related to communication and NPD by the studied companies and suppliers, which shows that these points should be worked on as to better such companies' cooperative NPD performance. It was also possible to identify a higher valuation of questions comprised in the work project and technological subsystems, the ones towards the procedures included in the development process and in the tools used during the process, respectively.

The application of the questionnaire and the data analysis gave the companies a diagnosis of the relationship they have with their suppliers during the NPD process. This analytical method also offers the companies a way to monitor the main factors that influence the supplier involvement in addition to allowing for the possibility of developing projects that cause the improvement of the performance of the relationships that companies have with their suppliers during NPD.

\section{REFERENCES}

1. Bititci, U., Turner, T., Mackay, D., Kearney, D., Parung, J., Walters, D., Managing synergy in collaborative enterprise, Prod Plan Control, 2007, 18, 6, 454-465.

2. Hartley, J.L., Meredith, J.R., Mc Cutcheon, D., Kamath, R.R., Suppliers' contributions to product development: an exploratory study, IEEE T Eng Manage, 1997, 44,3, 258-267.

3. Twigg, D., Managing product development within a design chain, Int J Oper Prod Man, 1998, 18, 5, 508-524.

4. Wasti, S.N., Liker, J.K., Collaborating with suppliers in product development: a US and Japan comparative study, IEEE T Eng Manage, 1999, 46, 4, 444-460.

5. Mikkola, J.H., Skjoett-Larsen, T., Early Supplier Involvement: Implications for New Product Development Outsourcing and SupplierBuyer Interdependence, Global Journal of Flexible Systems Management, 2003, 4, 4, 31-41.

6. Ragatz, G., Hanfield, R.B., Scannell, T.V., Success factors for integrating suppliers into new product development, J Prod Innovat Manag, 1997, 14, 3, 190-202.

7. Hanfield, R.B., Ragatz, G.L., Petersen, K.J., Monczka, R.M., Involving suppliers in new product development, Calif Manage Rev, 1999, 42, 1, 59-82.

8. Quesada, G., Syamil, A., Doll, W.J., OEM new product development practices: the case of the automotive industry, J Supply Chain Manag, 2006, 42, 3, 30-40.

9. Laseter, T.M., Ramdas, K., Product types and supplier roles in product development: an exploratory analysis, IEEE T Eng Manage, 2002, 49, 2, 107-118.

10.Ro, Y.K., Liker, J.K., Fixson, S.K., Evolving models of supplier involvement in design: The deterioration of the Japanese model in US auto, IEEE T Eng Manage, 2008, 55, 2, 359377.

11.Wagner, S.M., Indirect and direct supplier development: performance implications of individual and combined effects, IEEE T Eng Manage, 2010, 57, 4, 536-546.

12.Pereira, R., Ro, Y.K., Liker, J.K., Product Development and Failures in Learning from Best Practices in US Auto: a supplier perspective, IEEE T Eng Manage, 2014, 61, 3, 545-556.

13.Brown, S.L., Eisenhardt, K.M., Product development: past research, present findings, and future directions, Acad Manage Rev, 1995, 20, 2, 343-378.

14.Lau, A.K.W., Supplier and customer involvement on new product performance: contextual factors and an empirical test from manufacturer perspective, Ind Manage Data Syst, 2011, 111, 6, 910-942, 2011.

15.Zhao, Y., Cavusgil, E., Cavusgil, S.T., An investigation of the black-box supplier integration in new product development, $J$ Bus Res, 2014, 67, 6, 1058-1064.

16.Guimarães, L.B., Ribeiro, J.L.D., Renner, J.S., Oliveira, P.A.B., Worker evaluation of a macroergonomic intervention in a Brazilian footwear company, Appl Ergon, 2014, 45, 4, 923-935.

17.Schmitz, H., Knoringa, P., Learning from global buyers, J Dev Stud, 2000, 37, 2, 177-205. 
18.Navas-Alemán, L., The impact of operating in multiple value chains for upgrading: the case of the Brazilian furniture and footwear industries, World Dev, 2011, 39, 8, 13861397.

19.Schmitz, H., Global competition and local cooperation: success and failure in the Sinos Valley, World Dev, 1999, 27, 9, 1627-1650.

20.Hendrik, H.W., Kleiner, B.M., Macroergonomics: an introduction to work system design, Santa Monica, CA, Human Factors and Ergonomic Society, 2001, 10-82.

21.Chung, S.A., Kim, G.M. Performance effects of partnership between manufacturers and suppliers for new product development: the supplier's standpoint, Res Policy, 2003, 32, 4, 587-603.

22.Clark, K.B., Project scope and project performance: the effect of parts strategy and supplier involvement on product development, Manag Sci, 1989, 35, 10, 12471263.

23.Clark, K.B., Fujimoto, T., Product development performance: strategy, organization, management in the world auto industry, Boston, Harvard Business School Press, 1991, 67-97.

24. Helper, S., How much has really changed between U.S. automakers and their suppliers, Sloan Manage Rev, 1991, 32, 4, 15-28.

25.Womack, J.P., Jones, D.T., Ross, D., The machine that changed the world, New York: Simon \& Schuster Inc, 1991, 104-138.

26.Birou, L.M., Fawcet, S.E., Supplier involvement in integrated product development: a comparison of US and European practices, Int J Phys Distrib Logist Manag, 1994, 24, 5, 4-14.

27.Dyer, J.H., Specialized supplier networks as a source of competitive advantage: evidence from auto industry, Strategic Manage J, 1996, $17,4,271-291$.

28.Liker, J.K., Sobek II, D.K., Ward, A.C., Cristiano, J.J., Involving suppliers in product development in the United States and Japan: evidence for set-based concurrent engineering. IEEE T Eng Manage, 1996, 43,2, 165-178.
29.Bidault, F., Depress, C., Butler, C., The drivers of cooperation between buyers and suppliers for product innovation, Res Policy, 1998, 26, 7-8, 719-732.

30.Sobek II, D.K., Ward, A.C., Liker, J.K., Toyota's principles of set-based concurrent engineering, Sloan Manage Rev, 1999, 40, 2, 67-83.

31.Wynstra, F., Ten Pierick, E., Managing supplier involvement in new product development: a portfolio approach, European Journal of Purchasing and Supplier Management, 2000, 6, 1, 49-57.

32.De Toni, A., Nassimbeni, G., A method for the evaluation of suppliers co-design effort, Int J Prod Econ, 2001, 72, 2, 169-180.

33.Primo, M.A.M., Amundson, S.D., An exploratory study of the effects of supplier relationships on new product development outcomes, J Oper Manag, 2002, 20, 1, 33-52.

34.Spina, G., Verganti, R., Zotteri, G., Factors influencing co-design adoption: drivers and internal consistency, Int $J$ Oper Prod Man, 2002, 22, 12, 1354-1366.

35.Liker, J.K., Choi, T.Y., Building Deep Supplier Relationships, Harvard Bus Rev, 2004, 82, 12, 104-113.

36. Perona, M., Saccani, N., Integration techniques in costumer-supplier relationships: an empirical research in the Italian industry of household appliances, Int J Prod Econ, 2004, 89, 189-205.

37.Van Echtelt, F.E.A., Wynstra, F., Van Weele, A.J., Strategic and operational management of supplier involvement in new product development: a contingency perspective, IEEE T Eng Manage, 2007, 54, 4, 644-661.

38. Wasti, S.N., Liker, J.K., Risky business or competitive power? Supplier involvement in Japanese product design, J Prod Innovat Manag, 1997, 14, 5, 337-355.

39.Ballé, F., Ballé, M., Lean Development, Business Strategy Review, 2005, Autumn.

40.Mensendiek, A., Mitri, R., Contracting a Development Supplier in the Face of a CostCompetitive Second Source of Supply, IEEE T Eng Manage, 2014, 61, 3, 438-449. 
41. Hua, S.Y., Wemmerlov, U., Product change intensity in the personal computer industry: A study of firm-supplier innovation, IEEE $T$ Eng Manage, 2006, 53,3, 348-360.

42. Maffin, D., Braiden, P. Manufacturing and suppliers roles in product development. International Journal of Production Economics, 2001, 9, 2, 205-213.

43. Kamath, R.R., Liker, J.K., A second look at Japanese product development, Harvard Bus Rev, 1994, 72, 6, 154-170.

44.Twigg, D., Managing the design/ manufacturing interface across firms, Integrated Manufacturing Systems, 2002, 13, 4, 212-221.

45.Pasmore, W.A., Design effective organizations: the sociotechnical systems perspective, USA, John Wiley \& Sons, 1998, 118-214.

46.Sobrero, M., Roberts, E.B., The tradeoff between efficiency and learning in interorganizational relationships for product development, Manag Sci, 2001, 47, 4, 493511.

47.Teece, D.J., Profiting from technological innovation: implications for integration, collaboration, licensing and public policy, Res Policy, 1986, 15, 6, 285-30.

48.Jorde, T., Teece, D., Competition and cooperation: striking the right balance, Calif Manage Rev, 1989, 31, 3, 25-37.

49. Wheelwright, S.C., Clark, K., Revolutionizing product development: quantum leaps in speed, efficiency, and quality, New York: The Free Press, 1992, 57-86.

50.Becker, M.C., Zirpoli, F., Organizing new product development: knowledge holling-out and knowledge integration - the FIAT auto case, Int J Oper Prod Man, 2003, 23, 9, 10331061.

51.Møller, M.M., Johansen, J., Boer, H., Managing buyer-supplier relationships and interorganisational competence development, Integrated Manufacturing Systems, 2003, 14, 4, 369-379.

52. Fowles, S., Clark, W., Innovation networks: good ideas from everywhere in the world, Strategy \& Leadership, 2005, 33, 4, 46-50.
53. Moreira, A.C., Supplier-buyer collaboration in new product development: four case studies involving SMEs, Braz J Oper Prod Manag, 2005, 2, 1, 05-24.

54.Tidd, J., Bessant, J., Pavitt, K., Managing innovation: integrating technological market and organizational change, 3aed., John Wiley \& Sons, 2005, 67-94.

55.Lai, F., Zhang, M., Lee, D.M., Zhao, X., The impact of supply chain integration on mass customization capability: an extended resource-based view, IEEE T Eng Manage, 2012, 59, 3, 443-456.

56.Petersen, K.J., Hanfield, R.B., Ragatz, G.L., A Model of Supplier Integration into New Product Development, J Prod Innovat Manag, 2003, 20, 4, 284-299.

57. Nellore, R., The impact of supplier visions on product development, J Supply Chain Manag, 2001, 37, 1, 27-36.

58.Littler, D., Leverick, F., Bruce, M., Factors affecting the process of collaborative product development: a study of UK manufacturers of information and communications technology products, J Prod Innovat Manag, 1995, 12, 1, 16-32.

59.De Matta, R., Lowe, T.J., Wu, L., Managing Product Variety in a Supply Chain, IEEE T Eng Manage, 2015, 62, 1, 4-17.

60.Humphreys, P.K., Shiu, W.K., Chan, F.T.S., Collaborative buyer-supplier relationships in Hong Kong manufacturing firms, Supply Chain Manag, 2001, 6, 4, 152-162.

61.Ward, A.C., Liker, J.K., Cristiano, J.J., Sobek II, D.K., The second Toyota paradox: how delaying decisions can make better cars faster, Sloan Manage Rev, 1995, Spring, 43-61.

62.Dyer, J.H., Hatch, N.W., Using suppliers networks to learn faster, Sloan Manage Rev, 2004, Spring, 45, 56-63.

63.Cusumano, M.M., Nobeoka, K., Thinking Beyond Lean: How Multi Project Management is Transforming Product Development at Toyota and other Companies, New York: The Free Press, 1998, 51-101.

64.Karlsson, C., Ahlström, P., The difficult Path to Lean Product Development, J Prod Innovat 
Manag, 1996, 13, 4, 283-295.

65. Hillebrand, B., Biemans, W.G., Links between internal and external cooperation in product development: an exploratory study, J Prod Innovat Manag, 2004, 21, 2, 110-122.

66.Chiu, M.C., Kremer, G.E.O., An Investigation on Centralized and Decentralized Supply Chain Scenarios at the Product Design Stage to Increase Performance, IEEE T Eng Manage, 2014, 61, 1, 114-128.

67.Yin, R.K., Case study research: Design and methods, 3rd Ed, Thousand Oaks, CA: Sage publications, 2003, 37-66.

68.Stone, H., Sidel, J., Oliver, S., Woolsey, A., Singleton, R.C., Sensory evaluation by quantitative descriptive analysis, in M.C. Gacula (Ed.), Descriptive Sensory Analysis in Practice, Scottsdale, Arizona: Food \& Nutrition Press, 1997, 23-60.

69.Cronbach, L.J., Coefficient alpha and the internal structure of test, Psychometrika, 1951, 6, 3, 297-334.
70.Fonseca, L.M.C.M., Ferro, R.L., A Management Trinity: Employee Satisfaction, Customer Satisfaction and Economic Performance, Int J Ind Eng Manag, 2016, 7, 1, 25-30.

71.Hair Jr., J.F., Tatham, R.L., Anderson, R.E., Black, W., Multivariate data analysis with Reading, 4th Edition, Englewood Cliffs, NJ: Prentice Hall, 1995, 20-60.

72.Zhou, J., Li, T., Xu, B., Chen, W., Investigation of children's plantar pressure distribution with varied angle of hallux, Leather and Footwear Journal, 2015, 15, 1, 3-14.

(C) 2017 by the author(s). Published by INCDTPICPI, Bucharest, RO. This is an open access article distributed under the terms and conditions of the Creative Commons Attribution license (http:// creativecommons.org/licenses/by/4.0/). 